\title{
Juizado especial cível federal como instrumento facilitador do acesso à justiça
}

\author{
Special civil court federal and facilitator of access to justice
}

Luiz Alberto Pereira Ribeiro ${ }^{1}$

Mariana Resende Sanzovo ${ }^{2}$

\begin{abstract}
Resumo
0 presente estudo versa sobre como que, com a criação do instituto dos Juizados Especiais Cíveis Federais, foi facilitado às pessoas menos favorecidas o acesso à Justiça em suas disputas contra a União e seus entes federais. 0 assunto escolhido tem a pretensão de expor acerca dos benefícios trazidos com a gênese da Lei №. 10.259, de 12 de julho de 2001, com enfoque aos Juizados Especiais Federais Cíveis. Os resultados obtidos demonstram que a Lei dos Juizados Especiais Federais reflete uma maior aproximação do cidadão com a justiça distante e descrente, pois oferta uma forma de prestação jurisdicional que vem de encontro aos menos favorecidos, inseridos em uma sociedade complexa, permitindo, através de sua informalidade, um contato direto entre as partes, seja o juiz e testemunhas. A desburocratização tão desejada pela população e idealizada pelos operadores do direito, concretizouse na criação de um microssistema condizente com a realidade social em que se insere.
\end{abstract}

Palavras Chave: Acesso à justiça; Juizados Especiais Cíveis Federais; Justiça Federal.

\begin{abstract}
This study aims to show how that with the creation of the Office of the Special Civil Courts Federal, was facilitated the disadvantaged access to justice in their disputes against the Union and its federal entities. The subject chosen purport to expound on the benefits brought to the genesis of Law. 10.259 of July 12, 2001, with a focus on Special Federal Courts Civil Courts. The results show that the Law of Special Federal reflects a closer approximation of the citizen with justice distant and cynical, as a way of bid adjudication which comes against the disadvantaged, embedded in a complex society, allowing, through its informality, a direct contact between the
\end{abstract}

\footnotetext{
${ }^{1}$ Mestre em Direito Negocial pela Universidade Estadual de Londrina. Diretor do Curso de Direito da Pontifícia Universidade Católica do Paraná (PUC/PR campus Londrina). Professor da Universidade Estadual de Londrina (UEL), da Pontifícia Universidade Católica do Paraná (PUC/PR campus Londrina), da Fundação Escola do Ministério Público em Londrina (FEM PAR), da UNIVEL (Especialização) e da Escola Superior de Advocacia da OAB/PR. Professor e Coordenador da Pós-graduação de Direito do Trabalho e Direito Processual do Trabalho da PUCPR, campus Londrina. Advogado militante nas áreas trabalhista e cível. E-mail: luiz@ pblr.adv.br

2 Acadêmica Graduada em Letras Estrangeiras Modernas - habilitação em língua inglesa e respectivas literaturas pela Universidade Estadual de Londrina (2009).Bacharel em Direito pela Pontifícia Universidade Católica do Paraná - campus Londrina (2010). E-mail: mrsanzovo@ hotmail.com
}

Revista de Direito Púbuco, Londrina, V. 6, N. 2, P. 142-159, AGO/SET. 2011. 
parties, be the judge and witnesses. The bureaucracy so desired by the population and idealized by law operators, realized in the creation of a micro consistent with the social reality in which it operates.

Keywords: Access to Justice; Federal Court; Special Civil Court Federal.

\section{Introdução}

0 presente trabalho, em uma breve explanação e sem o intuito de esgotar o tema, objetiva abordar como que, com a criação do instituto dos Juizados Especiais Cíveis Federais (JEF), foi facilitado às pessoas menos favorecidas o acesso à Justiça em suas disputas contra a União e seus entes federais.

0 assunto escolhido tem a pretensão de expor acerca dos benefícios trazidos com a gênese da Lei no. 10.259, de 12 de julho de 2001, com enfoque aos Juizados Especiais Federais Cíveis.

Em um país que se diz 'democrático,' uma justiça rápida e eficiente sempre foi e será o ideal de todos os cidadãos. Deste modo, no objetivo de aprimorar o acesso da sociedade à Justiça, as inovações que esta lei trouxe será o foco desta presente pesquisa. Acesso esse, facilitado por meio da solução rápida das causas de menor expressão econômica em face de causas de competência federal.

A criação dos Juizados Especiais tem entre seus fins o de satisfazer a chamada demanda reprimida, permitindo o acesso ao Judiciário para pessoas que não possuem condições sociais e financeiras de suportar gastos e aguardar o tempo e os procedimentos invariavelmente percorridos pelos processos ordinários.

\section{0 direito fundamental do acesso à justiça}

Em um Estado Democrático de Direito, o acesso à justiça visa garantir um princípio básico: a isonomia. Não se pode duvidar que o acesso à justiça é o mais básico e um dos mais eminentes direitos do homem. Hoje, o direito à igualdade significa direito de igualdade de oportunidades ao acesso à justiça. Deste modo, para que este seja efetivado, faz-se necessário que os ritos processuais cumpram sua função social, pois não há como reconhecer a existência do direito sem efetivá-lo por meio da instrumentalidade processual.

Nesse sentido, ensinam M auro Capelletti e Bryant Garth (1988, p. 11-13) que: 


\begin{abstract}
De fato, o direito ao acesso efetivo tem sido progressivamente reconhecido como sendo de importância capital entre os novos direitos individuais e sociais uma vez que a titularidade de direitos é destituída de sentido, na ausência de mecanismos para sua efetiva reivindicação. 0 acesso à justiça pode, portanto, ser encarado como requisito fundamental - o mais básico dos direitos humanos - de um sistema jurídico moderno e igualitário que pretenda garantir, e não apenas proclamar os direitos de todos. 0 enfoque sobre 0 acesso - o modo pelo qual os direitos se tornam efetivos - também caracteriza crescentemente 0 estudo moderno do processo civil [...]. 0 acesso não é apenas um direito social fundamental crescentemente reconhecido; ele é, também, necessariamente, o ponto central da moderna processualística. Seu estudo pressupõe um alargamento e aprofundamento dos objetivos e métodos da moderna ciência jurídica.
\end{abstract}

Cumpre observar que, 0 ordenamento jurídico atual tem sempre enfatizado uma série de princípios e garantias processuais no intuito de oportunizar à parte uma ordem jurídica mais justa. 0 acesso à justiça é 0 epicentro que converge toda esta previsão legal de princípios e garantias que, em sua interação, objetivam uma pacificação com justiça.

0 acesso à justiça não se identifica com a simples admissão ao processo, ou com 0 ingresso em juízo. É muito mais que isso. Segundo Cintra, Grinover e Dinamarco (2010, p. 39), para que haja um efetivo acesso à justiça é indispensável que o maior número possível de pessoas seja admitido a demandar e a defender-se adequadamente (inclusive em processo criminal), sendo também condenáveis as restrições quanto a determinadas causas (pequeno valor, interesses difusos); mas, para a integralidade do acesso à justiça, é preciso isso e muito mais.

Para que a efetividade do processo atinja seu objetivo de fazer justiça e busca uma solução aos litígios, é preciso se ater às finalidades de todo o sistema. É necessário que os órgãos do judiciário não criem barreiras econômicas que impeçam ou não oportunizem que as pessoas litiguem ou busquem a propositura de sua ação ou defesa. Assim, a Constituição Federal, em seu art. 5ำ, inc. LXXIV prevê a oferta da assistência jurídica integral e gratuita. Esta previsão constitucional deve ser cumprida tanto na esfera cível quanto na penal, de modo que ninguém seja privado de ser atendido pelo juízo por falta de recursos pecuniários.

Da mesma forma, em todo o processo é eminente que o devido processo legal não deixe de ser observado, ou seja, é preciso que o procedimento seja sempre devidamente respeitado de modo que as partes possam gozar do contraditório. Deste modo, sendo este outro princípio fundamental inerente ai acesso à justiça, o juiz deve permitir que haja um diálogo com o juízo, sendo que aquele deve ser ativo e participativo na busca de elementos 
para uma melhor instrução. É oportuno dizer que o juiz não deve ser um mero expectador do processo, sendo conferido a ele o poder de atuar ativamente nos atos processuais.

Deve-se mencionar também, com base em Cintra, Grinover e Dinamarco (2010, p. 41), o juiz deve pautar-se pelo critério de justiça, seja ao apreciar a prova, ao enquadrar os fatos em normas e categorias jurídicas ou ao interpretar textos da lei. Deste modo, o judiciário não há que exigir das partes provas tão precisas e exaustivas dos fatos alegados, tornando dificultosa a demonstração destes, impedindo que a parte exerça seu direito material.

É sobremodo importante salientar que a expressão acesso à justiça deve significar o acesso a um processo justo, o acesso ao devido processo legal, a garantia de acesso a uma Justiça imparcial; a uma Justiça igual, contraditória, dialética, cooperatória, que coloque a disposição das partes todos os instrumentos e meios necessários que lhes possibilitem concretamente sustentarem suas razões, produzirem suas provas, influírem sobre a formação do convencimento do juiz (FORTES, 1998, p. 51).

Para que 0 acesso à justiça, como um direito social, se concretize, é essencial mais do que uma mudança nos ritos e procedimentos jurídicos. É eminente que haja uma transformação de mentalidade, de forma que tal direito possa ser visto pelos consumidores da jurisdição (cidadãos), e não somente sob a ótica do Estado.

\section{A constituição federal de 1988 e a promessa de um novo acesso à justiça}

0 acesso à justiça enquanto direito fundamental que é e, sendo protegido pela Constituição da República, no estudo ora desenvolvido, será visto sob a concepção positivista dos direitos fundamentais. Ou seja, compreendido como direito incorporado ao regime jurídico por força de normas constitucionais, bem como demais fontes jurídicas aplicáveis à nossa nação.

Em nosso ordenamento, até a aprovação da Lei Federal n. ${ }^{\circ}$ 9.099, de 26 de setembro de 1995, as pequenas causas podiam ser julgadas pelo Juizado de Pequenas Causas, no qual o critério de valor para sua competência em âmbito cível consistia em 20 (vinte) vezes 0 valor do salário-mínimo vigente na época. 0 rito célere adotado e os bons resultados alcançados demonstraram uma conquista sob dois prismas: a primeira quanto à viabilização ao cidadão de uma justiça descomplicada e célere; e a segunda quanto à 
concretização dos ideais de efetividade canalizados pelo acesso à ordem jurídica (FORTES, 1998, p. 76).

Após quatro anos da experiência dos Juizados de Pequenas Causas, a Constituição Federal impôs a fundação dos Juizados Especiais Cíveis, para causas de menos complexidade e, para as de menos potencial ofensivo para área Criminal.

A previsão encontra-se no artigo 98, I, que assim defende:

Art. 98. A União, no Distrito Federal e nos Territórios, e os Estados criarão: I - juizados especiais, providos por juízes togados, ou togados e leigos, competentes para a conciliação, o julgamento e a execução de causas cíveis de menor complexidade e infrações penais de menor potencial ofensivo, mediante os procedimentos oral e sumaríssimo, permitidos, nas hipóteses previstas em lei, a transação e o julgamento de recursos por turmas de juízes de primeiro grau;

Desta forma, o juizado de pequenas causas a que se refere o texto constitucional equivale ao Juizado Especial, passando a ter cunho obrigatório, conforme expressamente previsto no Capítulo III, da Carta Magna, que trata do Poder Judiciário.

De igual forma, Dinamarco (2001, p. 33.) defende que:

[...] a Lei dos Juizados Especiais constitui um reflexo processual das opções sóciopolíticas contidas na ordem constitucional: o novo processo que institui (não mero procedimento) apresenta um conjunto de idéias que constitui resposta adequada às exigências contidas nos princípios constitucionais do processo (processo acessível, aberto, gratuito em primeiro grau de jurisdição, ágil, simples, e concentrado, permeável a um grau elevadíssimo de participação das partes e do juiz).

Nesse sentido vale dizer que 0 acesso à justiça pode significar ir além fronteiras e incluir mecanismos que facilitem não apenas o ingresso em juízo, mas também oportunizar instrumentos adequados que auxiliem a parte durante 0 desenvolvimento do processo. Assim, pode citar, a título de exemplo, a redução de custas (ou a ausência delas, em determinados casos), duração razoável do processo, minimização de oportunidades de impugnação às decisões, bem como a efetiva participação na relação processual.

Em outras palavras, 0 acesso à justiça não representa somente ter mero acesso aos tribunais, mas sim ter sua tutela jurisdicional atendida quando se tem razão. Esta tutela pode ser prestada tanto à parte autora da demanda, quando há procedência de seu pedido, bem como à parte ré, sendo improcedente. Em grande parte dos casos, ainda assim, não 
basta que o conflito de interesses seja solucionado, pois, em muitas vezes, ele não é adequadamente acolhido, tempestivo e efetivo às partes.

\section{A lei no. 9.099/95 aplicada subsidiariamente aos juizados especiais federais}

Tendo em vista as demandas apresentarem diversas diferenças, existem algumas peculiaridades a serem observadas tanto pelo aplicador do direito quanto pelo intérprete em relação à aplicação subsidiária da Lei no. 9.099/95. Esta lei trata de um procedimento de resolução das lides entre os particulares, enquanto a Lei no 10.259/01 trata da solução dos litígios entre particulares a União e seus entes. Deste modo, nas ações que correrão nos Juizados especiais Federais Cíveis, em um dos pólos da relação processual estará presente uma entidade da Administração pública federal, autárquica e fundacional, englobando as demandas que versam sobre direito público, enquanto que no Juizado Especial Cível estadual terá a prevalência das relações de direito privado entre particulares.

No que diz respeito à subsiariedade destas leis, deve-se enfatizar que estes dois sistemas possuem origens e finalidade comuns. Deste modo, as normas específicas que se referem aos Juizados Especiais Federais que não possibilitam a solução, deve-se buscar subsídios na Lei no. 9.099/95.

Assim preceitua 0 art. 1o da Lei ํㅜ 10.259/01, in verbis: “Art. 1ํ São instituídos os Juizados Especiais Cíveis e Criminais da Justiça Federal, aos quais se aplica, no que não conflitar com esta Lei, o disposto na Lei no 9.099, de 26 de setembro de 1995."

Destarte, os operadores do direito deverão estar atentos para as particularidades no que diz respeito ao âmbito federal.

Sobre o tema, José Eduardo Carreira Alvim(2002, p. 9-10.) ensina que:

Como a Lei №. 9.099/95 disciplina um procedimento de resolução das lides entre particulares (pessoas físicas, jurídicas e morais), não po deria o legislador prever sua aplicação no âmbito federal sem fazer essa reserva legal expressa, porquanto a Lei no. 10.259/01 trata da solução de conflitos diversos entre particulares e a Administração Pública federal, autárquica e fundacional; e muitos dos preceitos aplicáveis aos juizados especiais estaduais não se ajustam aos juizados especiais federais, razão pela qual a aplicação subsidiária da Lei №. 10.259/2001 deve respeitas esse requisito da compatibilidade. 
No entanto, não foquemos na aplicação subsidiária da Lei no 9.099/95, pois é a Lei no 10.259/01 que traz inovações e peculiaridades. Veja-se:

a) limitação da competência às causas de até 60 (sessenta) salários mínimos (art. 3ㅇ);

b) possibilidade da concessão de medidas sumárias ou de urgência (art. 4ํ);

c) sistema recursal, com limitação do número de recursos (art. 50);

d) possibilidade de comunicação dos atos processuais de citação e intimação por meio eletrônico (art. 8ㅇ);

e) eliminação dos prazos diferenciados em favor da Fazenda Pública (Art. 188, CPC). No âmbito dos Juizados Especiais Federais não há prazo em quádruplo e em dobro para a defesa e recurso, respectivamente, e o reexame necessário (arts. 9o e 13ㅇ);

f) surgimento do representante judicial - terceiro designado pela parte autora para representá-lo, sem a necessidade de ser advo gado (caput do art. 10);

g) a possibilidade de conciliação e transação das partes, inclusive para os representantes judiciais das pessoas jurídicas de direito público (art. 10, § único);

h) inversão do ônus da prova em favor do autor, devendo a entidade pública ré fornecer ao Juizado a documentação que disponha para o esclarecimento da causa, apresentando-a até instalação da audiência de conciliação (art. 11);

i) criação do procedimento de uniformização de interpretação de lei federal quando houver divergência entre decisões sobre questões de direito material proferidas por Turmas Recursais (art. 14);

j) eliminação do processo autônomo de execução (art. 16 e 17);

h) dispensa do pagamento de precatório, no prazo de 60 (sessenta) dias contados da requisição feita pelo juiz mediante ofício, além da possibilidade de o próprio juiz sequestrar numerário das contas dos entes públicos em caso de descumprimento da decisão (art. 17).

Estas são inovações trazidas pela Lei no. 10.259/2001, que algumas serão abordadas ao longo deste trabalho, visam possibilitar, à demanda mais reprimida dos jurisdicionados, 0 acesso à justiça.

A representação desta nova Lei na ordem normativa reflete uma maior aproximação do cidadão com a justiça distante e descrente, pois oferta uma forma de prestação jurisdicional que vem de encontro aos casos mais comuns, inseridos em uma sociedade complexa, permitindo, através de sua informalidade, um contato direto entre as 
partes, seja 0 juiz e testemunhas. A desburocratização tão desejada pela população e idealizada pelos operadores do direito, concretizou-se na criação de um microssistema condizente com a realidade social em que se insere.

0 que importa frisar é que, pela ordem, primeiro devemos estudar a Lei №. 10.259/2001, dando primazia a este estudo; após, se nada for indicado pela norma do Juizado Federal, partir para o cotejo da Lei №. 9.099/1995 com a Lei ํㅡ. 10.259/2001, pois a diferença substancial entre uma e outra é gritante no que tange, além dos aspectos já mencionados, à legitimidade das partes (entes públicos federais) e correspondente forma de execução (estritamente mandamental); e, em terceiro plano, verificar e estudar se a solução trazida pelo Código de Processo Civil atende aos princípios dos Juizados. Pois, em caso contrário, é mais conveniente não aplicá-lo, fazendo uso de outras regras legais que atendam os princípios.

\section{Considerações gerais dos Juizados Especiais Cíveis Federais}

Os Juizados Especiais não podem ser definidos como uma 'justiça de classe inferior.' Não representam também uma justiça 'menor' ou uma solução alternativa discriminatória. Deste modo, não refletem qualquer elemento indicativo que resulte em um desprestígio ou diminuição para resolução de controvérsias, mas sim buscava-se, sobretudo, responder rapidamente aos reclamos populares através da agilização dos procedimentos.

Assim, para Tourinho Neto (2002, p. 45.), esta forma diferenciada de prestar jurisdição representa um avanço legislativo de origem, sobretudo, constitucional, que surge no intuito de amparar as necessidades de todos os cidadãos, especialmente os menos abastados, proporcionando uma justiça apta a oferecer uma prestação de tutela simples, rápida, econômica e segura, com o potencial de diminuir a litigiosidade contida, que é talvez o mais eminente fator em sede federal, a prestação de tutela jurisdicional de modo muito mais célere, informal, e verdadeiramente efetiva.

Sendo um modo alternativo de solucionar as lides de pequeno valor dos cidadãos, e com vistas a garantir 0 acesso aos direitos subtraídos por meio de uma prestação jurisdicional mais célere e econômica, os Juizados Especiais Federais justifica a inclusão de novos princípios ao nosso ordenamento. 
No entanto, não se trata de negar importância da aplicação dos princípios constitucionais tradicionais, como o devido processo legal, o contraditório e a ampla defesa. Mas diz respeito a garantias essenciais de um Estado Democrático de Direito.

Em consonância, além dos princípios processuais disciplinados na Constituição Federal, os princípios da Oralidade, Simplicidade, Informalidade, Economia processual e Celeridade são os princípios informadores do instituto dos Juizados Especiais expressos nas Leis $n \cong .0 .999 / 95$ e n. 10.259/2001.

\section{Do procedimento - questões gerais}

0 procedimento no Juizado instaura-se com a apresentação da petição inicial à Secretaria deste. A inicial será escrita ou oral, sendo esta quando a parte comparece pessoalmente ao Juizado e um servidor reduz a termo seu pedido em formulário padrão. Esta peça deverá respeitar os devidos pressupostos processuais, bem como as condições da ação, contendo: a) os nomes e as qualificações das partes; b) causa de pedir; c) pedido certo e determinado; d) valor da causa; e) documentos como: comprovante de residência em nome do autor; RG, CPF, bem como demais documentos indispensáveis para a instrução do feito.

Dependendo da particularidade de cada caso, a parte poderá pleitear alguma medida sumária, seja ela cautelar ou antecipatória. No entanto, em se tratando de JEF, a antecipação da tutela somente será concedida nos termos da Sentença. (Enunciado I da $1^{a}$ Turma do JEF do DF).

Em seguida, competirá ao juiz examinar a inicial podendo, desde logo, indeferi-la (proferindo sentença sem exame de mérito), determinar que a parte autora a emende, ou, estando na devida ordem, determinará a citação da parte ré. Com o ato de citação, a parte ré será cientificada da ação de que é movida contra ela, sendo intimada a apresentar resposta.

Dependendo da natureza da ação, muitas vezes de faz necessário a realização de uma perícia judicial. Tomemos como exemplo as ações em que a parte autora ingressa com um pedido de concessão de auxílio-doença ou, constatada a incapacidade total e permanente, a concessão de aposentadoria por invalidez; nestas ações é indispensável 
perícia médico-judicial para que seja elaborado um laudo pericial. 0 perito designado é um profissional de confiança do juízo, de preferência, especialista em perícia médica.

Destaca-se que, se acontecer de a parte autora ausentar-se da perícia médica e, embora devidamente intimada, não procurar justificar o motivo pelo qual se ausentou da perícia, com fulcro no artigo 51, I da Lei no. 9.099/1995, o feito será extinto sem resolução de mérito. De fato, essa atitude demonstra desinteresse na resolução do litígio, o que contraria a celeridade, tão exigida, aliás, pela própria sociedade em face do Poder Judiciário. Deste modo, para rápida solução do litígio, não basta 0 andamento célere e desburocratizado do feito nos cartórios judiciais, mas também se faz necessária a fundamental colaboração das partes e de seus procuradores no cumprimento de seus ônus processuais.

Após terem sido devidamente citadas, em determinadas demandas se faz necessário que as partes sejam intimadas a comparecerem em audiência no intuito de obterem uma conciliação. Este é um dos objetivos dos Juizados, oportunizar um acordo entre as partes, visando uma solução efetiva e célere. Nesta Audiência, e se posteriormente se fizer necessário uma audiência de instrução, deverão ser seguidas as disposições da Lei $\mathrm{n}$. 9.099/95. No entanto, em se tratando de Juizado Federal, não é possível o pedido contraposto, pois equivaleria a transmudar a condição de rés às pessoas discriminadas no artigo $6^{\circ}, \mathrm{I}$.

Na prática o que acontece é que, não se chegando a uma conciliação, e estando presentes as partes bem como as testemunhas designadas, o magistrado, na mesma audiência, fará a oitiva destas como forma de instrução do feito, mais uma vez almejando e respeitando um dos princípios bases do Juizado Federal - a celeridade.

Terminada a instrução, proferirá o juiz a sentença, a qual deverá observar os elementos previstos no artigo 38 da Lei n. 9.099/95, ou seja, ser necessariamente líquida, discriminado os elementos de convicção do julgador, sendo dispensado relatório dos fatos, mas com um breve resumo dos pontos relevantes ocorridos em audiência.

\section{Redução da carga de demandas na Justiça Federal}

Segundo o material 'Justiça Federal ao alcance de Todos', disponível no sítio eletrônico da Justiça Federal do Estado do Paraná, a Justiça Federal tem como missão "a 
pacificação dos conflitos que envolvem os cidadãos e a Administração Pública Federal, em diversas áreas. Nos processos da Justiça Federal aparecem, de um lado, os particulares e de outro, a União, as empresas públicas, autarquias e fundações públicas federais ou os conselhos de fiscalização profissional. A Justiça Federal também tem a missão de processar e julgar os chamados crimes federais, que atingem bens e interesses de qualquer um dos entes federais citados, além de outros crimes definidos na Constituição e na lei como sendo de sua competência (tráfico transnacional de drogas, contrabando e descaminho etc.)."

Com o surgimento deste instituto, observa-se que o mito da Justiça Federal célere, informal e com prestação de tutela efetiva, transforma-se em realidade, à medida que com a gênese dos Juizados Especiais Cíveis se fazem presentes, seja por meio de Varas Especializadas, ou de Juizados Itinerantes ou Adjuntos.

Não é de se olvidar que com a instituição dos JEF em 12 de julho de 2001 através da Lei no. 10.259 foi possibilitado em muito o acesso ao foro federal ao menos favorecidos e, através da rapidez na tramitação dos litígios, põe fim a uma das maiores mazelas da Justiça, qual seja a demora na solução dos conflitos.

Assim, este instituto visa atender ao justo anseio de todo cidadão em ser ouvido quanto aos seus problemas jurídicos. É a justiça do cidadão comum que postula uma rápida solução para sua ação de benefício previdenciário ou assistencial, que muitas vezes se faz urgente, e entre outras de acordo com este novo instituto na esfera federal.

\section{Juizado Especial Cível Federal como instrumento facilitador do acesso à justiça}

Os Juizados Especiais Federais, assim como os Juizados Especiais Estaduais através da Lei 9.099/95, visam um procedimento ágil, simples e de baixo custo, demonstrando uma significativa luta pelo efetivo acesso à justiça.

O Juizado Especial Federal visa dar atenção ao anseio de todo o cidadão quanto aos seus problemas jurídicos. Deste modo, não há que se duvidar que o tão buscado acesso à justiça foi proporcionado com o surgimento da Lei no. 10.259/2001, haja vista que deu a oportunidade da parcela menos favorecida da sociedade como as pessoas físicas, as microempresas e as empresas de pequena porte, serem parte nas ações perante os JEF. Esta Lei permitiu que, através da rapidez na tramitação dos litígios, colocasse um fim em uma das maiores moléstias da Justiça: a demora na solução dos litígios. 
Na mesma linha, destaquemos a questão das custas do processo. As custas, sendo um outro grande empecilho da para os menos favorecidos buscarem à Justiça para solução de seus conflitos, passou também a ter privilégios no âmbito dos Juizados. Assim como os Juizados Especiais Estaduais, os federais deram continuidade à experiência no sentido de que, com exceção à interposição de recursos, não há que se falar em custas judiciais e honorários advocatícios, o que tem beneficiado os hipossuficientes, ou seja, a grande parcela da população de nosso país.

Como já dito anteriormente, não há a necessidade da contratação de advogado nas ações de competência dos Juizados Federais. No entanto, vale destacar que, apesar de ser mais um aspecto auxiliador do acesso à justiça, a figura do advogado é de grande eminência para garantir o efetivo contraditório. Representado por um operador do Direito, a parte poderá ter, muitas vezes, um processo mais justo e democrático.

Desta feita, os Juizados não foram criados somente para a tentativa de autocomposição (conciliação), mas também para o desenvolvimento do processo, em todos os termos e na forma procedimental instituída pela própria Lei, em consonância com o rito previsto na Lei n. 9.099/95, o que representa viabilidade jurídica à prestação da tutela jurisdicional por intermédio da prolação de uma sentença de mérito (nos termos do art. 269, do Código de Processo Civil), como também a efetivação forçada da pretensão acolhida pelo julgador, por intermédio da execução específica, ou por meio da atuação autoritária da lei em benefício ao autor (vencedor da demanda).

Entre outras atribuições dos Juizados Federais que propiciam o acesso ao judiciário aos cidadãos inclui-se também a definição do funcionamento dos JEF em caráter itinerante. É o que prevê o parágrafo único do artigo 22 da lei n. 10.259/2001, que quando exigirem as circunstâncias, os Juizados Federais poderão ser itinerantes mediante autorização prévia do Tribunal Regional Federal a que estiver hierarquicamente vinculado o Juiz coordenador do respectivo juizado, com antecedência mínima de 10 (dez) dias.

Acentuamos ainda, que a atribuição dos Juizados Especiais Federais é de acordo com as particularidades e necessidade de cada região. Ou seja, de acordo com o artigo 23 da Lei n. 10.259/2001, o Conselho da Justiça Federal poderá limitar, por até três anos a competência dos Juizados Especiais Cíveis, atendendo a organização dos serviços judiciários 
ou administrativos. Joel Dias Figueira Júnior (2002, p. 146) complementa em sua obra, "Juizados Especiais Cíveis e Criminais", que:

\begin{abstract}
Nesse sentido, o conselho da Justiça Federal baixou a Resolução n. 252, de 18 de dezembro de 2001, limitando pelo período de seis meses (até 30 de agosto de 2002) a competência dos Juizados Especiais Cíveis em três Regiões, a saber: 3a , 4⿳亠丷 e 5a Região para atuação exclusiva em causas relacionadas com a previdência e assist6encia social nas varas instaladas das capitais e interior; 2ạ. Região, competência cível em geral nas varas instaladas no Rio de Janeiro e em Vitória. Outrossim, registra-se que a Resolução mencionada é omissa a respeito da competência dos Juizados Especiais Federais integrantes da 1a. . Região.
\end{abstract}

No entanto, observa-se que esta determinação do Conselho se estendeu a outras subseções da Justiça Federal, e muitas mantiveram sua especialidade em demandas previdenciárias até hoje. Isto é prova de que os Juizados Federais se preocuparam, mais uma vez, em atender as necessidades e os anseios dos cidadãos.

Em busca de um processo de resultados ou verdadeiramente efetivo, encontramos no microssistema dos Juizados Especiais a figura da justiça participativa. Por intermédio de uma democratização do Judiciário, a integração harmoniosa do povo e a administração da justiça se faz necessário em prol da simplificação e agilização de maneira a reduzir gradativamente a litigiosidade contida e, sobretudo, enfatizar a autocomposição, mediante a intervenção desses terceiros auxiliares.

Deste modo, nesta busca de uma contextualização do judiciário, a Lei n. 9.099/95 reservou uma Seção (II) específica para versar sobre três eminentes personagens dos Juizados Especiais: o juiz togado, o conciliador e o juiz leigo, restringindo os dois últimos ao patamar de auxiliares da justiça (art. 5ำ a 7ํ). Estes são aspectos em que a Lei permite uma maior aproximação da comunidade à resolução de seus conflitos intersubjetivos.

Além de tudo, a Lei no. 10.259/01 facilitou consideravelmente o desafogamento da Justiça Federal, oferecendo um melhor atendimento à grande parcela da população que, em muitas vezes, não tem acesso à prestação jurisdicional por acreditarem na morosidade da Justiça devido ao grande montante de processos em tramitação, bem como na dificuldade em arcar com as custas processuais. 


\section{Juizados Especiais Cíveis Federais - aspectos propiciadores do acesso à justiça}

0 acesso à justiça é valor imprescindível ao processo democrático, por permitir ao cidadão a defesa dos seus interesses e à sociedade solução pacífica dos conflitos. A ampliação do acesso à justiça importa em conferir instrumentos aos cidadãos não somente para defender interesses individuais, mas igualmente concedendo-lhe maior possibilidade de participação política, notadamente quanto à defesa dos interesses difusos e coletivos. Pode-se afirmar que alguns dos principais obstáculos ao movimento de ampliação e democratização do acesso à J ustiça são os seguintes:

a) a falta de informação; b) os altos custos do processo; c) a lentidão burocrática; d) 0 excesso de 'formalismo'; e e) as diferenças entre as partes. Para ele, esses limites influenciam, decisivamente, a capacidade dos cidadãos em defender seus interesses e direitos, pois podem imobilizar ou mesmo intimidar suas ações.

Dentre os aspectos propiciadores do acesso à justiça que integram o perfil dos Juizados Federais, podemos citar que é uma justiça muito mais simples, pois adota um rito simplificado além de sua competência em decidir causas de menor complexidade. Ademais, é uma Justiça mais econômica, tendo em vista ser dotada de uma estrutura mais enxuta em comparação com a Justiça Comum, não deixando de ser muito mais eficiente.

Em termos pecuniários, o Juizado Federal é uma instituição mais barata a medida em que somente haverá custas na via recursal, alem da possibilidade de peticionar sem a necessidade de contratar advogado.

Ressalta-se ainda que é uma Justiça mais aberta, ou seja, mais acessível e preocupada com a camada carente da população, sendo comum encontrar pessoas bem pobres recorrendo ao auxílio dos Juizados, apagando a imagem de que a Justiça Federal é uma Justiça de elite. Além disso, este órgão tende a se aproximar muito mais da população, como é o caso da existência dos Juizados Itinerantes e outros meios, buscando ampliar ao máximo 0 acesso à Justiça.

Saliente-se ainda que é um órgão mais ágil, tendo em vista a abolição de prazos especiais para a Fazenda Pública e de outras prerrogativas, como o duplo grau obrigatório, os recursos contra decisões interlocutórias e o sistema de precatório. De igual forma, é uma instituição mais dialogal, mais comunicativa, pois existe a possibilidade de acordo e 0 respeito aos princípios orientadores da oralidade e da informalidade. Ademais, está além de 
outros órgãos no sentido de ser uma Justiça mais moderna, tendo em vista a possibilidade de comunicação dos atos via processo eletrônico, audiências gravadas, e em muitas regiões a existência dos Juizados Virtuais, com autos digitais substituindo os autos em papel, alem de outras tecnologias.

Deste modo, cumpre observar que, como base nestas características, no Juizado Especial Federal o processo deixa de ser um fim em si mesmo para cumprir seu papel que deveria sempre ter sido: um instrumento para que direito material violado pudesse ter tutelado.

O processo, como meio civilizado de solução de litígios, é um instrumento da jurisdição, ou melhor, do Poder Judiciário, que, sendo um dos poderes do Estado brasileiro, tem sua razão de existir diretamente vinculada ao dever não só de auxiliar na construção de uma sociedade livre, justa e solidária, mas também de promover o bem de todos, sem preconceitos de origem, raça, sexo, cor, idade e quaisquer outras formas de discriminação (art. 3ํ, incisos I e IV, da Constituição Federal).

Os Juizados Especiais Cíveis são instrumentos de poder, criados pelos mandatários do povo, para servi-lo, de modo a solucionar-lhes as lides decorrentes da vida social, as quais por muito tempo foram deixadas de lado pelo Estado brasileiro. Eles têm por objetivo resgatar do seio da sociedade a litigiosidade contida, aquela demanda reprimida que não encontrava um canal institucional para sua solução.

Por constituírem os Juizados a forma mais democrática de atendimento àquelas causas de pequeno valor, o Estado, justamente, deve preencher as expectativas da população geradas em torno daqueles, sabendo que, assim agindo, aumentará o grau de confiança depositado pelo cidadão no seu governo.

Com a instauração dos Juizados Especiais Federais, foi dado ao Poder Judiciário a possibilidade de restaurar sua legitimidade perante os cidadãos, ofertando o acesso à justiça de maneira célere, eficaz e sem privilégios.

\section{Conclusão}

Em virtude dessas considerações, acreditamos que a Lei $n$ ㅇ. 10.259 de 12 de julho de 2001, que instituiu os Juizados Especiais Federais Cíveis e Criminais, contribuiu em muito na questão do acesso à Justiça. Oportunizou meios para a prestação jurisdicional mais 
efetiva e eficiente. Além disso, cremos também que a implantação deste instituto perante a Justiça Federal concederá ao Judiciário o aparelhamento e os mecanismos necessários e suficientes para a agilização da Justiça, com um considerável decréscimo da carga de trabalho das varas e tribunais, além do objetivo, que em nossa opinião, seria o mais eminente de facilitar 0 acesso à Justiça. Ademais, propicia 0 atendimento da enorme demanda reprimida dos cidadãos, que encontram certa dificuldade em ter acesso à prestação jurisdicional em virtude de fatores como custos, ou mesmo pela morosidade excessiva na tramitação dos processos.

Não obstante, é bom lembrar que não basta uma legislação de última geração para solução dos problemas; é necessário também que os operadores do Direito absorvam essa mentalidade a fim de que esse instrumento, colocado à disposição tanto dos profissionais do direito quanto da população economicamente menos desprovida, seja um auxílio efetivo na eliminação dos conflitos em busca da consecução de uma efetiva cidadania. Deste modo, estar-se-á cumprindo uma dos mais eminentes fundamentos da Constituição da República Federativa do Brasil de 1988, expresso em seu inciso III, do artigo 1o, qual seja, a Dignidade da Pessoa Humana.

\section{Referências}

ALVIM, José Eduardo Carreira. Juizados Especiais Federais. Rio de Janeiro: Forense, 2002.

BRASIL. Constituição da República Federativa do Brasil de 1988. Disponível em: বhttp://www.planalto.gov.br/ccivil_03/constituicao/constitui\%C3\%A7ao.htm>. Acesso em: 7 mar. 2010.

BRASIL. Lei n. ${ }^{0} 5.869$, de 11 de janeiro de 1973. Institui o Código de Processo Civil. Disponível em: বttp://www.planalto.gov.br/ccivil_03/Leis/L5869.htm>. Acesso em: 3 jun. 2010.

BRASIL. Lei no 9.099, de 26 de setembro de 1995. Dispõe sobre os Juizados Especiais Cíveis e Criminais e dá outras providências. Disponível em:〈http://www.planalto.gov.br/ccivil/leis/L9099.htm>. Acesso em: 7mar. 2010.

BRASIL. Lei $n^{0} 10.259$, de 12 de julho de 2001. Dispõe sobre a instituição dos Juizados Especiais Cíveis e Criminais no âmbito da Justiça Federal. Disponível em: বttp://www.planalto.gov.br/ccivil/leis/LEIS_2001/L10259.htm>. Acesso em: 7 mar. 2010. 
BRASIL, Lei no 11.419, de 19 de dezembro de 2006. Dispõe sobre a informatização do processo judicial. Disponível em: «ttp://www.planalto.gov.br/ccivil_03/_ato20042006/2006/lei/l11419.htm>. Acesso em: 25. ago. 2010.

BRASIL, Lei complementar n‥ 123, de 14 de dezembro de 2006. Institui o Estatuto Nacional da M icroempresa e da Empresa de Pequeno Porte. Disponível em:

«ttp://www.receita.fazenda.gov.br/legislacao/leiscomplementares/2006/leicp123.htm>. Acesso em: 20. ago. 2010.

BRASIL, Provimento no 01, de 10 de maio de 2004. Determina normas complementares para regulamentação do Sistema eproc. Disponível em:

४http://www.jfsc.gov.br/ead/PDF/Provimento\%2001-04.pdf>Acesso em: 30. ago. 2010.

BRASIL, Resolução no. 13, de 11 de março de 2004. Instituiu o E-proc. Disponível em: বttp://www.jfpr.gov.br/ninf/eproc.pdf>Acesso em: 25. ago. 2010.

CANOTILHO, J. J. Gomes. Direito Constitucional e teoria da constituição. Coimbra: Almedina, 2002.

CAPPELLETII, M auro; GARTH, Bryant. Acesso à justiça. Porto Alegre: Fabris, 1988.

CHIM ENTI, Ricardo Cunha. Teoria e prática dos juizados especiais cíveis estaduais e federais: (Lei n. 9.099/95 - parte geral e parte cível, comentada artigo por artigo em conjunto com a Lei dos Juizados Federais - Lei n. 10.259/2001) / Ricardo Cunha Chimenti. - 8. Ed. - São Paulo: Saraiva, 2005.

CINTRA, Antônio Carlos de Araújo ; GRINOVER, Ada Pellegrini ; DINAM ARCO, Cândido Rangel. Sociedade e tutela jurídica. In: .Teoria geral do processo. 26. ed. São Paulo: Malheiros, 2010.

CONSELHO dos Juizados Especiais Federais (COJEF). Enunciados FONAJEF. Disponível em: ४http://www.trf4.jus.br/trf4/institucional/institucional.php?id=enum_fonajefs $>$. Acesso em: 2 ago. 2010.

DINAM ARCO, Cândido Rangel. A instrumentalidade do processo. São Paulo: RT, 2001.

ESCOLA Superior da M agistratura Federal. Justiça Federal ao alcance de todos. Disponível em: 〈ttp://www.jfpr.jus.br/institucional/justica_federal_para_todos.pdf>Acesso em: 23. ago.2010.

Estatística M ensal da Justiça Federal de 1 o Grau da 4a Região - M ovimentação Processual. Disponível em: ঝttp://www.jfpr.jus.br/naj/estatisticas_mensais.php> Acesso em: 09. out.2010. 
FORTES, Simara Carvalho Duarte. 0 juizado especial como instrumento do direito de acesso à justiça: uma abordagem sobre sua competência. 1998. f. Dissertação (M estrado em Direito) Universidade Federal do Paraná, Curitiba, 1998.

GIRALDI, Renata. Justiça Estadual tem seis juízes para cada 100 mil habitantes, diz CNJ. Disponível em: ঝttp://www1.folha.uol.com.br/folha/brasil/ult96u506553.shtml>. Acesso em: 29 set. 2010.

LIM A, George Marmelstein. Organização e Administração dos Juizados Especiais Federais. Administração da Justiça Federal: concurso de M onografias - 2004. Disponível em: বhttp://web51.hosting.xpg.com.br/xpg2.0/0/g/e/georgemlima/jefs. pdf>Acesso em: 29/09/2010.

M ARINONI, Luiz Guilherme ; ARENHART, Sérgio Cruz. Curso de processo civil: processo de conhecimento. 6. ed. rev., atual. e ampl. São Paulo: Revista dos Tribunais, 2007. V. 2

SANTOS, M aria Ferreira dos. Juizados Especiais Cíveis e Criminais: Federais e Estaduais, tomo II - 7. ed. rev. e atual - São Paulo: Saraiva, 2009. - (Coleção sinopses jurídicas; 15).

TOURINHO NETO, Fernando da Costa ; FIGUEIRA JÚNIOR, Joel Dias. Juizados especiais cíveis e criminais: comentários à Lei 10.259, de 10.07.2001. São Paulo: Revista dos Tribunais, 2002. 